\title{
Looking for RED FLAGS: identifying and supporting patients at risk of adverse psychological responses to genetic counselling and testing
}

\section{S Buscombe}

From Familial Aspects of Cancer 2011 Research and Practice: A combined meeting of kConFab, Australian Breast Cancer Family Study, Australian Colorectal Cancer Family Study, Australian Ovarian Cancer Study, Family Cancer Clinics of Australia and New Zealand and kConFab

Kingscliff, Australia. 23-26 August 2011

There is a significant body of research indicating having a genetic condition is emotionally burdensome for the individual and their family. One goal of cancer genetic counselling is to assist patients to adapt to the news that they and family members are at significantly increased risk of developing cancer. Numerous studies have shown that the majority of patients who attend cancer genetic services do not report significantly increased long-term psychological distress. However, a small number of patients present with pre-existing complex psychological issues or particular personality traits which are not readily apparent. This subgroup of individuals may experience adverse psychological responses and complex adjustment challenges following their participation in the genetic counselling process.

Submit your next manuscript to BioMed Central and take full advantage of:

- Convenient online submission

- Thorough peer review

- No space constraints or color figure charges

- Immediate publication on acceptance

- Inclusion in PubMed, CAS, Scopus and Google Scholar

- Research which is freely available for redistribution 